\title{
Scieuced corcentrates
}

\section{Making the True 'CP' Ligand}

J.G. Cordaro, D. Stein, H. Rüegger, and H. Grützmacher*, Angew. Chem. Int. Ed. 2006, 45, 6159-6162.

ETH Zürich

The preparation of cyaphide $\left(\mathrm{CP}^{-}\right)$, the phosphorus equivalent of cyanide, has been a challenge for many years. In this communication, Grützmacher and coworkers report a rational synthesis to access the first 'true' metal $\mathrm{CP}$ complex; $\left[\mathrm{RuH}(\mathrm{CP})(\mathrm{dppe})_{2}\right]$ (dppe = bis(1,2-diphenylphosphinoethane)) being isolated and fully characterized.

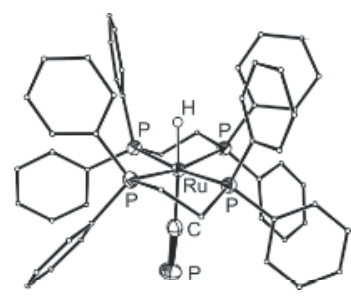

\section{Controlled Release of Volatile Aldehydes and Ketones by Reversible Hydrazone Formation - 'Classical' Profragrances are Getting Dynamic}

B. Levrand, Y. Ruff, J.-M. Lehn*, and A. Herrmann*, ISIS-ULP,

Chem. Commun. 2006, 2965-2967.

Strasbourg and Firmenich SA, Genève

Dynamic mixtures obtained as an equilibrium by reversible reaction of fragrance aldehydes and/or ketones with a hydrazide in water to form acylhydrazones were found to be efficient in controlling the release of highly volatile biologically active compounds from solid surfaces.

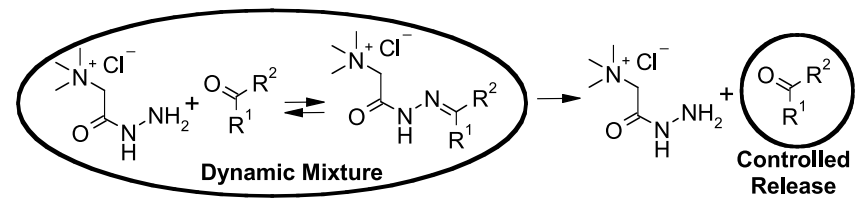

\section{Synthesis and Pairing Properties of $\alpha$-Tricyclo-DNA}

S.P. Scheidegger and C.J. Leumann*, Chem. Eur. J. 2006, 12 8014, DOI: 10.1002/chem.200600597.

Universität Bern

Starting from $\alpha$-tc-nucleosides, phosphoramidite building blocks of $\alpha$-tricyclo-DNA ( $\alpha$-tc-DNA) covering all four natural bases were prepared. Like natural DNA, $\alpha$-tc-DNA binds preferentially to parallel nucleic acid complements through the Watson-Crick duplex formation, favoring RNA over DNA

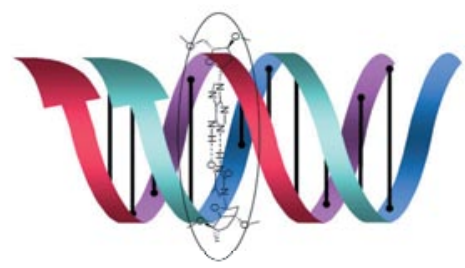

Iridium-Catalyzed Enantioselective Synthesis of Allylic Alcohols: Silanolates as Hydroxide Equivalents

I. Lyothier, C. Defieber, and E.M. Carreira*, Angew. Chem. Int. Ed. 2006, 45, 6204-6207.

ETH Zürich

Easy and direct access to enantioenriched molecules is of crucial importance for the synthesis of complex structures. Among the wide variety of methods, one of the most documented is the attack of a nucleophile onto an allylmetal intermediate yielding chiral allylic compounds with high enantiomeric excess. In this paper, it is shown that the iridiumcatalyzed addition of silanolates onto a large variety of allylic carbonates using chiral phosphoramidite ligands is feasible. This novel methodology directly provides highly enantioenriched allylic alcohols.



$\mathrm{R}=$ aryl and alkyl substituents $L^{*}=$ Feringa phosphoramidite

92-99\% ee and up to $88 \%$ yield

\section{Photoproduction of Proton Gradients with $\pi$-Stacked Fluorophore Scaffolds in Lipid Bilayers}

S. Bhosale, A.L. Sisson, P. Talukdar, A. Furstenberg, N. Banerji, E. Vauthey, G. Bollot, J. Mareda, C. Roger, F. Würthner, N. Sakai, and S. Matile*, Science 2006, 313, 84-86.

Université de Genève

Rigid $p$-octiphenyl rods were used for the formation of helical tetrameric $\pi$-stacks of naphthalene diimides that can span lipid bilayer membranes. In prepared lipid vesicles with quinone as electron acceptors and ethylenediaminetetraacetic acid as hole acceptors, transmembrane proton gradients take place during quinone reduction under irradiation with visible light. Supramolecular self-organization played the key role in that photoactivity.
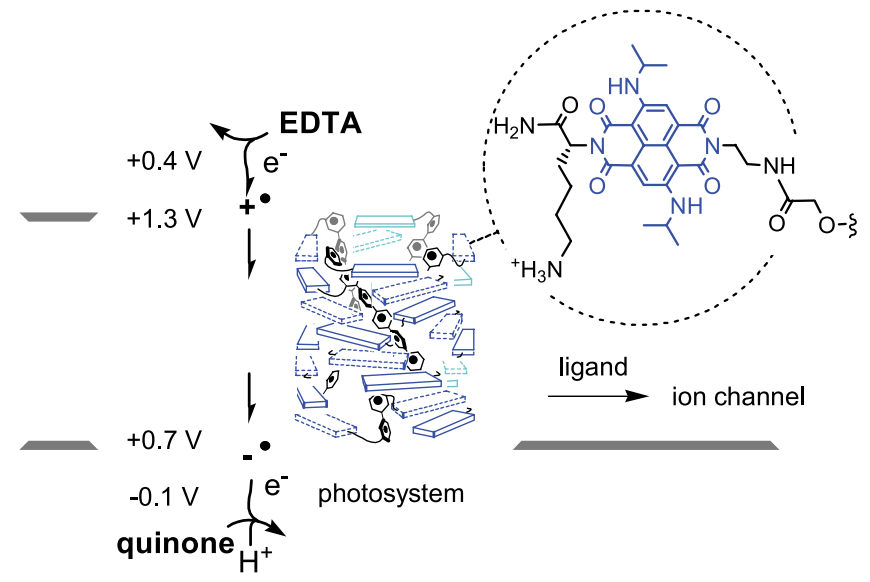

quinone $\mathrm{H}_{\mathrm{H}^{+}}^{\mathrm{e}^{-}}$photosystem

Prepared by M.-H. Gonçalves-Farbos; D. Linder; N. Mehanna; C. Nicolas; R. Novikov; J. Lacour 